\title{
LUTEINIZING HORMONE SECRETION DURING THE OESTROUS CYCLE OF THE EWE AS DETERMINED BY RADIO-IMMUNOASSAY
}

\author{
I. S. WHEATLEY AND H. M. RADFORD \\ C.S.I.R.O., Division of Animal Physiology, \\ Ian Clunies Ross Animal Research Laboratory, Prospect, \\ N.S.W. 2142, Australia
}

(Received 31st December 1968, revised 7th February 1969)

This note presents preliminary results on the use of a radio-immunoassay method involving the use of ${ }^{125} \mathrm{I}$ LH prepared by the method of Greenwood, Hunter \& Glover (1963) for the determination of $\mathrm{LH}$ in the blood of ewes throughout the oestrous cycle. Particular attention was paid to the period around oestrus. In the assay, $0.3 \mathrm{ml}$ plasma is incubated for $72 \mathrm{hr}$ at $4^{\circ} \mathrm{G}$ with $100 \mathrm{pg}{ }^{125} \mathrm{I} \mathrm{LH}(\sim 100 \mu \mathrm{c} / \mu \mathrm{g}$, vol $0.1 \mathrm{ml}$ in phosphate buffer, $0.05 \mathrm{M}$, $\mathrm{pH} 7 \cdot 4$, containing $0.25 \%$ bovine serum albumin, Fraction $\mathrm{V}$ ) and with $1.0 \mathrm{ml}$ of $1: 250,000 \mathrm{LH}$ antiserum, also diluted in phosphate buffer. After incubation, during which the ${ }^{125} \mathrm{I}$ LH and LH present in plasma compete for binding to the antiserum, $150 \mathrm{mg}$ talc is added to adsorb the hormone not bound by the antiserum (Rosselin, Assan, Yalow \& Berson, 1966). The talc is then separated by centrifugation, washed with $1.5 \mathrm{ml}$ phosphate buffer and its radio-activity counted in a $\gamma$-spectrometer. The radio-activity of ${ }^{125} \mathrm{I} \mathbf{~ L H}$ adsorbed to talc in the absence of antiserum is used as a measure of the labelled hormone available for binding to antiserum. From this measure, the ratio of antiserum-bound radio-activity (B) to radio-activity present on talc $(F)$ is determined. This ratio is related to a curve obtained from similarly treated standard LH solutions to which $0.3 \mathrm{ml}$ sheep plasma is added, immediately before the talc, to allow for non-specific binding of hormone to plasma constituents. ${ }^{125} \mathrm{I}$ LH and standard LH solutions were prepared from NIH-LH-Sl.

The antiserum used was prepared in a mare against bovine LH, and examination of its specificity (Text-fig. 1) showed that, as expected, it bound bovine LH even more strongly than ovine LH. In addition, the antiserum bound both ovine and bovine thyrotrophic hormone (TSH) almost as well as ovine $\mathrm{LH}$, and there was a small reaction against ovine follicle stimulating hormone (FSH); there was no reaction against ovine growth hormone (GH), adrenocorticotrophic hormone (ACTH), ovine prolactin, pregnant mare serum (PMSG) or human chorionic gonadotrophin (HCG). Serial dilution of a sheep plasma, estimated to have a high LH concentration, gave a curve essentially parallel to that of NIH-LH-sl. The completeness of competition between TSH and LH has negated attempts to adsorb anti-TsH activity from the antiserum. In the present study, the problem of relative contributions of TSH and LH was overcome 
by comparing the levels of LA in normal ewes with those in ewes treated with thyroxine to inhibit TsH release.

Assays were performed on plasma obtained by jugular venipuncture in twenty trained Merino and Border Leicester $\times$ Merino ewes throughout the oestrous cycle. Blood was collected once in $24 \mathrm{hr}$, except at the expected time of oestrus when samples were taken for several days at intervals which varied from

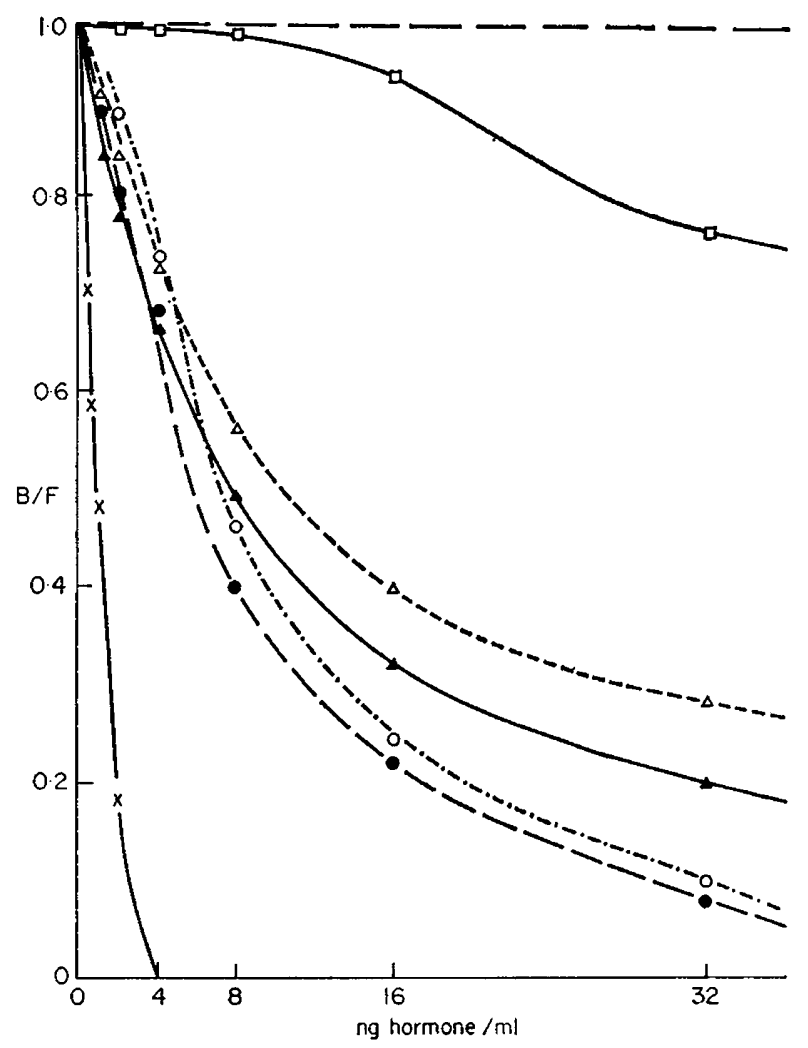

TEXT-FIG. 1. Cross-reaction of hormonal preparations with bovine LH antiserum. $x$, NIH-LH-B5;, NIH-LH-s $; ; O$, sheep plasma serially diluted; $\Delta$, NIH-TSH-s2; $\Delta$, NIH-TSH-B3; $\square$, NIH-FSH-sl. - - , No cross-reaction with ovine $\mathrm{GH}$, up to $256 \mathrm{ng} / \mathrm{ml}$ (potency 2 i.u.) $\mathrm{mg}$ ); ACTH (Acton, Andrews Laboratories) up to $20 \mathrm{~m}$-units/ml; prolactin (NIH-P-s6) up to $256 \mathrm{ng} / \mathrm{ml}$; PMSG (Burroughs Wellcome), up to $50 \mathrm{i} . \mathrm{u} . / \mathrm{ml}$; HCG (Schering), up to 20 i.u. $/ \mathrm{ml}$.

$4 \mathrm{hr}$ to $30 \mathrm{~min}$. The onset and cessation of oestrus were determined by testing ewes individually with vasectomized rams at 2 or $4 \mathrm{hr}$ intervals, commencing 1 to 2 days before the expected onset of oestrus. Thyroxine-treated ewes were injected subcutaneously with $1 \mathrm{mg}$ L-thyroxine/day commencing 3 to 4 days before expected oestrus, and were given a further injection of 1 or $2 \mathrm{mg} \mathrm{L}$ thyroxine intravenously at the start of oestrus.

The changes in LH concentration of jugular plasma throughout the oestrous cycle in two representative ewes are shown in Text-fig. 2; this pattern of response was common to all animals. The concentration of $\mathrm{LH}$ in plasma was low during most of the oestrous cycle, ranging from 5 to $15 \mathrm{ng} / \mathrm{ml}$. There 
was a steady decline in LH concentration from the end of oestrus to Day 14 or 15 of the cycle. Thereafter, there was an increase which, however, was small compared with the dramatic rise in jugular LH concentration which occurred shortly after the start of oestrus. From observations on forty oestrous periods, this rise began $4.6 \mathrm{hr}$ (S.D. $\pm 4 \cdot 3$ ) after the start of oestrus and reached a peak

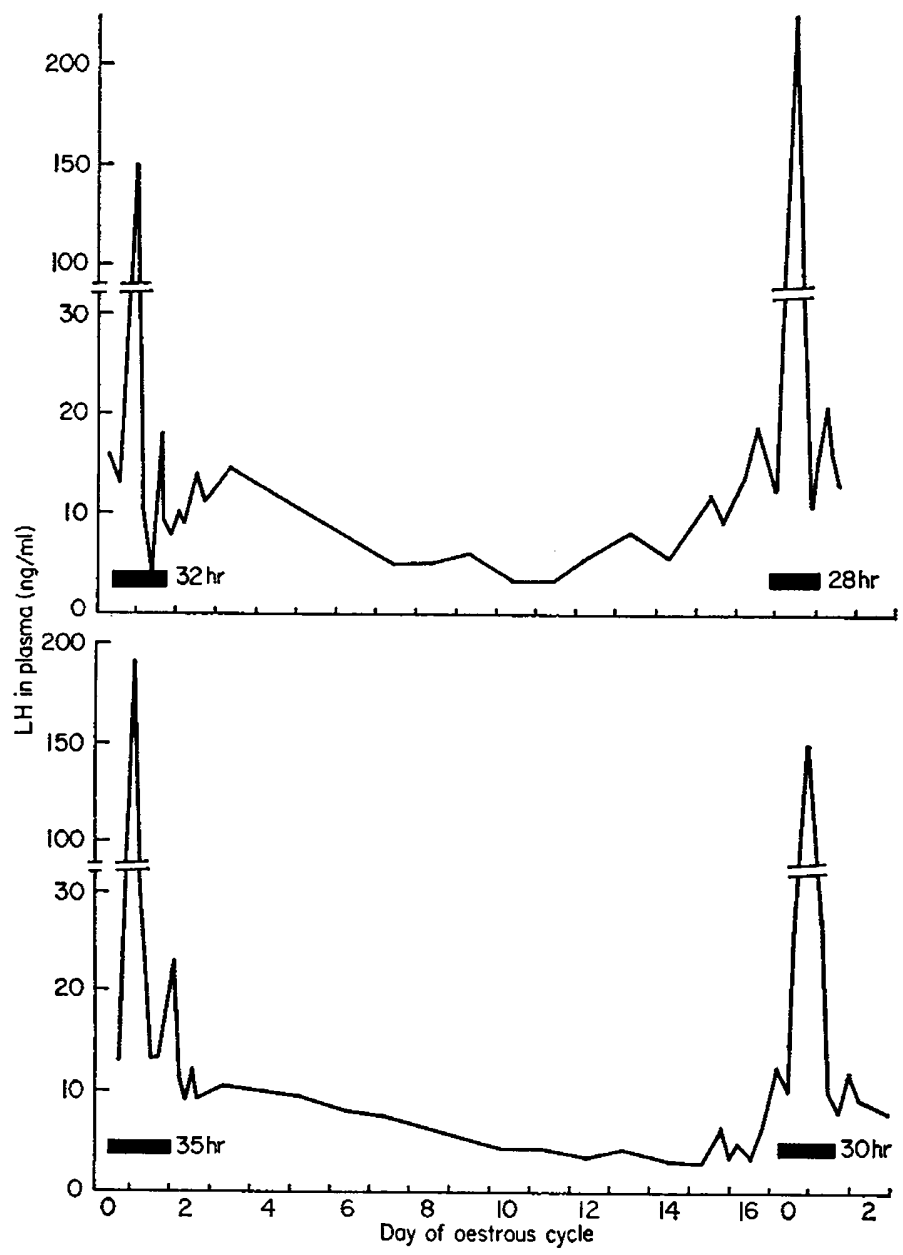

TEXT-F1G. 2. Changes in LH concentration of jugular plasma throughout the oestrous cycle of two Border Leicester $\times$ Merino ewes. Horizontal black bars represent period of oestrus. The day on which oestrus started is indicated as Day 0.

by $12.0 \mathrm{hr}$ (S.D. $\pm 4 \cdot 2$ ). Peak values ranging from 46 to $460 \mathrm{ng} / \mathrm{ml}$ (mean 172) were recorded at this time and by $20.7 \mathrm{hr}$ after onset of oestrus (S.D. $\pm 5 \cdot 3$ ) values had decreased almost to pre-oestrous levels. There was no detectable difference between thyroxine-treated and untreated ewes in the magnitude or timing of the peak during oestrus, indicating that the peak represents secretion of $\mathrm{LH}$ at this time, and is unlikely to be due to TSH secretion. The peak occurred $19.9 \mathrm{hr}$ (S.D. \pm 4.6 ) before the end of oestrus, and $25.7 \mathrm{hr}$ before ovulation as 
determined by laparotomy in five ewes. There was no apparent difference between Merino and Border Leicester $\times$ Merino ewes.

These results are consistent with the recent observations of Pelletier, Kann, Dolais \& Rosselin (1968) and Geschwind \& Dewey (1968), who also used radio-immunoassay to determine $\mathrm{LH}$ in the plasma of ewes throughout the oestrous cycle. Further, the results provide accurate information on the time relationships between the limits of the oestrous period and the oestrous LH peak. The rise in LH during oestrus occurred apparently several hours later than the time at which pharmacological agents will uniformly block ovulation in the ewe (Robertson \& Rakha, 1965; Radford, 1966). It seems likely, then, that the neural stimulus for $\mathrm{LH}$ release and $\mathrm{LH}$ release itself are not synchronous in this species, a suggestion made first by Robertson \& Rakha (1965) on the basis of their data on pharmacological blockade of ovulation, together with earlier studies on the pituitary content of gonadotrophin (Robertson \& Hutchinson, 1962).

We are indebted to Dr R. B. Snook and Dr W. H. Hansel of Gornell University for the preparation and supply of the bovine LH antiserum, and to $\mathrm{Mr} \mathrm{H}$. Buitenhuis for technical assistance.

\section{REFERENCES}

Geschwind, I. I. \& Dewey, R. (1968) Dynamics of luteinizing hormone (LH) secretion in the cycling ewe: a radioimmunoassay study. Proc. Soc. exp. Biol. Med. 129, 451.

Greenwood, F. C., Hunter, W. M. \& Glover, J. S. (1963) The preparation of ${ }^{131}$ I-labelled human growth hormone of high specific radioactivity. Biochem. $7.89,114$.

Pelletier, J., Kann, G., Dolais, J. \& Rosselin, G. (1968) Dosage radioimmunologique de l'hormone lutéinisante plasmatique chez le mouton. Comparaison avec le dosage biologique de LH par la diminution de l'acide ascorbique ovarien, et exemple d'application aux mesures de la LH sanguine chez la brebis. C.r. hebd. Séanc. Acad. Sci., Paris, 266, 2352.

RADFORD, H. M. (1966) Pharmacological blockade of ovulation in the ewe. F. Endocr. 34, 135.

Robertson, H. A. \& Hutchinson, J. S. M. (1962) The levels of FSH and LH in the pituitary of the ewe in relation to follicular growth and ovulation. J. Endocr. 34, 143.

Robertson, H. A. \& Rakha, A. M. (1965) The timing of the neural stimulus which leads to ovulation in the sheep. 7. Endocr. 32, 383.

Rosselin, G., Assan, R., Yalow, R. S. \& Berson, S. A. (1966) Separation of antibody-bound and unbound peptide hormones labelled with iodine-131 by talcum powder and precipitated silica. Nature, Lond. 212, 355. 